\title{
Evolution of reproduction processes in the establishment and development of a company interaction system (on the example of oil and gas industry)
}

\author{
Eleonora G. Matugina \\ Department of Economics of Natural Resources \\ National Research Tomsk Polytechnic University \\ Tomsk, Russia \\ emk512542@mail.ru \\ Olga V. Pogharnitskaya \\ Department of Economics of Natural Resources \\ National Research Tomsk State University \\ Tomsk, Russia
}

\author{
Olga V. Vusovich \\ Deputy Dean for Academic Affairs \\ National Research Tomsk State University \\ Tomsk, Russia \\ dgim@tic.tsu.ru \\ pov@tpu.ru
}

\begin{abstract}
The article is to study the system of company interactions with economic entities at various levels. The areas of collaboration and tools of common interests coordinating have been identified. The evaluation criteria of the effective interaction system focused on maintaining of sustainable production growth have been suggested. The study is based on the activities of PJSC Lukoil.
\end{abstract}

Keywords-reproductive processes, economic environment, economic entities, interaction system

\section{INTRODUCTION}

The operation of the economic entity (regardless of its industry) is related to interactions covering different areas (e.g. economic, social, environmental) and influencing its performance effectiveness. The content of these interactions is constantly changing both qualitatively and qualitatively. The transformations can be initiated by any participants of the system, projecting their decisions on the economic environment, and / or interaction, and / or behavior of economic entities involved.

In particular, oil and gas companies is taken as an example of the system described. the importance of which to ensure the smooth functioning of the economic system and to maintain the well-being of society can hardly be overestimated. Their importance in ensuring the smooth functioning of the economic system and maintaining of the well-being of society can hardly be overestimated.

\section{Methodology}

The dynamism of economic parameters requires a continuous adaptation of the company to the changing conditions, resulting in development of new, substantive solutions. In any case, creation of an institutional framework focused on regulating parameters of economic entities and their interactions. This happens within the framework of existing national regulations, not excluding, the company's proactive approach.

The variety of interactions of a company complicates the economic decisions making process updating the issues of selection and implementation of interaction forms and determination of the evaluation criteria.

As a condition of the growth of social welfare (significant strategic priority of the state), maintaining of the expanded reproduction covers all spheres of life.

The objective of the study is to evaluate the system of company interactions with economic entities at various levels and to identify the tools for coordinating collaboration areas and common interests, and maintaining the expanded reproduction. ${ }^{1}$

\footnotetext{
${ }^{1}$ The report on the sustainable development of PJSC Lukoil (2014) is taken as an evidence base of the study.
} 


\section{RESULTS AND DISCUSSIONS}

The economic entities, participating in the interactions are:

\section{Government.}

Its influence on the activities of companies constitutes the formation of the economic parameters of the environment, the decision-making boundaries of the entities, etc.

The interaction includes:

- economy in general (e.g., the Tax Code, the Government Resolution, the Federal Laws)

- industry (Orders of the Ministry of Natural Resources, Energy Ministry Orders, the Federal Law Concerning Subsurface Resources, the development strategies of oil and gas industry etc.)

- activities of individual enterprises (Order of the Federal Antimonopoly Service and the Ministry of Energy about the trade of oil products through the stock exchange of OJSC Rosneft, PJSC Lukoil, PJSC Gazprom; Government Executive Order about 12 sites on the shelf of the Russian Federation empowered to OJSC Rosneft etc.).

The company's interactions with the government is also carried out through the corporate social responsibility system including:

- interactions common to all forms of entities (e.g. payment of taxes, compliance with environmental regulations, etc.);

- company initiatives, including territorial peculiarities (see below);

- participation in the implementation of government programs. Thus, LLC Lukoil-SeveroZapadnefteprodukt participates in the program "Northern delivery" as a supplier of fuel and lubricants in the remote and inaccessible villages and production fields, located in the Nenets Autonomous District and the Komi Republic.

The difference between the first and the second forms is associated with the level of commitments implemented. Initiative activities of companies may be focused on the better implementation of existing regulations.

Thus, strategic goals of environmental safety of PJSC Lukoil include: achieving a 95\% level of utilization of oildissolved gas; effective management of greenhouse gas emissions; complete elimination of past environmental damage; reducing the number of pipeline failures, and rehabilitation of lands damaged as a result of those failures. [1]

\section{Regional authorities.}

One of the forms of interaction between a company and a regional government is an agreement on social and economic cooperation. Such agreements have been signed in the main territories of Lukoil presence - Leningrad region and St.
Petersburg, Komi Republic, Novomoskovsk administrative district, Kaliningrad and Arkhangelsk regions.

It must be noted, that this activity has a purposive character associated with the company's participation in solving problems of the territory. It is based on the coordinating interests of entities and involves problems monitoring, implementation of the programs, optimizing of collaboration between the leading company, local authorities and population. [2 ]

PJSC Lukoil is characterized by extensive differentiation of priorities (Table. 1).

TABLE 1 EXAMPLES OF SOCIAL AND ECONOMIC PARTNERSHIP

\begin{tabular}{|l|l|}
\hline & PRIORITY GUIDELINES \\
\hline $\begin{array}{l}\text { Republic } \\
\text { of Komi }\end{array}$ & $\begin{array}{l}\text { Construction and renovation of social infrastructure (cultural } \\
\text { and educational institutions, hospitals, sports facilities, etc.) }\end{array}$ \\
\hline $\begin{array}{l}\text { Leningra } \\
\text { d Region }\end{array}$ & $\begin{array}{l}\text { In 2013, Lukoil signed an agreement on long-term projects } \\
\text { (construction of new and reconstruction of existing facilities for } \\
\text { transportation and storage of oil and oil products; expansion of } \\
\text { the network of fuel stations). } \\
\text { The company undertook a commitment on building a pipeline } \\
\text { from the port of Primorsk to the marine terminal in Vysotsk, } 12 \\
\text { petrol stations and storage bitumen (in order to stabilize prices } \\
\text { for bitumen and increase the volume of road construction). }\end{array}$ \\
\hline $\begin{array}{l}\text { Vologda } \\
\text { Region }\end{array}$ & $\begin{array}{l}\text { The company is developing multiservice stations on the federal } \\
\text { roads in accordance with the Agreement; } 8 \text { petrol stations have } \\
\text { been purchased and 2 fuel stations have been constructed. }\end{array}$ \\
\hline
\end{tabular}

Building a communication system for identification of problems of the areas and assessment of their solutions requires interaction between the company and the region in parameters modeling . [3,4]

Thus, interests coordination of the entities, establishment of the company's image, increasing of the attractiveness of the region (in the aspect of attracting investments, skilled labor, etc.) are arranged.

PJSC Lukoil applies the following:

- annual public meetings in the business site regions;

- R\&D by independent organizations;

- coordinating and support of the subsidiaries;

- personal meetings with the leaders of regions and municipalities

The population is considered the end user of the initiatives announced, so it can be certified as a target consumer (Table 2).

TABLE 2. CHARITY AND SPONSORSHIP EXPENCES OF PJSC LUKOIL GROUP IN THE RUSSIAN FEDERATION [1]

\begin{tabular}{|l|c|c|c|c|c|}
\hline PARAMETERS & $\mathbf{2 0 1 0}$ & $\mathbf{2 0 1 1}$ & $\mathbf{2 0 1 2}$ & $\mathbf{2 0 1 3}$ & $\mathbf{2 0 1 4}$ \\
\hline TOTAL, million rubles /\%, & $1645 /$ & $2472 /$ & $2718 /$ & $2418 /$ & $2672 /$ \\
including & 100 & 100 & 100 & 100 & 100 \\
\hline SUPPORT OF ORPHANAGES & $45,5 /$ & $41,4 /$ & $85,2 /$ & $63,0 /$ & $32,0 /$ \\
AND EDUCATIONAL & 2,7 & 1,7 & 3,1 & 2,6 & 1,2 \\
INSTITUTIONS & & & & & \\
CHILDREN & & & & & \\
\hline EDUCATIONAL PROGRAMS & $130,0 /$ & $167,0 /$ & $143,6 /$ & $148 /$ & $170,5 /$ \\
& 8,0 & 6,8 & 5,3 & 6,1 & 6,4 \\
\hline SUPPORT OF HEALTHCARE & $59,8 /$ & $153,0 /$ & $21,9 /$ & $60,0 /$ & $79,0 /$ \\
INSTITUTIONS & 3,6 & 6,2 & 0,8 & 2,5 & 2,9 \\
\hline
\end{tabular}




\begin{tabular}{|lr|c|c|c|c|c|}
\hline CONTESTS OF SOCIAL AND & $59,7 /$ & $74,5 /$ & $86,3 /$ & $87,7 /$ & $87,7 /$ \\
CULTURAL PROJECTS & 3,6 & 3,0 & 3,2 & 3,6 & 3,3 \\
\hline SUPPORT OF PEOPLES OF & $146,5 /$ & $147,0 /$ & $155,0 /$ & $175,0 /$ & $217,0 /$ \\
THE FAR NORTH & & 9,0 & 5,9 & 5,7 & 7,2 & 8,1 \\
\hline PRESERVATION OF & $90,7 /$ & $215,6 /$ & $199,0 /$ & $139,0 /$ & $281,2 /$ \\
CULTURAL & AND & 5,5 & 8,7 & 7,3 & 5,8 & 10,5 \\
HISTORICAL HERITAGE & & & & & \\
\hline RELIGION FUNS & $68,1 /$ & $73,4 /$ & $113,0 /$ & $139,0 /$ & $191,6 /$ \\
& 4,1 & 3,0 & 4,2 & 5,8 & 7,1 \\
\hline PUBLIC FND & $186,0 /$ & $289,9 /$ & $376,3 /$ & $258,6 /$ & $519,8 /$ \\
ORGANIZATIONS & 11,3 & 11,7 & 13,8 & 10,7 & 19,5 \\
\hline TARGETED AID & $143,2 /$ & $104,2 /$ & $79,4 /$ & $91,0 /$ & $93,0 /$ \\
& 8,7 & 4,2 & 3,0 & 3,7 & 3,5 \\
\hline SPORT & $715,6 /$ & $1206 /$ & $1458 /$ & $1259 /$ & $1002 /$ \\
& 43,5 & 48,8 & 53,6 & 52,0 & 37,5 \\
\hline
\end{tabular}

According to the data provided, the greatest attention is paid to sport ( $37.5 \ldots 53.6 \%$ of the total costs).It is followed by public funds and organizations (10.7 ... 19.5\%).In recent years the costs for the preservation of cultural and historical heritage have been almost doubled (5.5\% in $2010-10.5 \%$ 2014).

\section{Human resources of the company.}

Any company is interested in maintaining / increasing the quality of the workforce as a condition of the effective functioning. Thus, not only respecting general regulations (pre-condition for the management legitimacy) but also investments in human capital, promoting its expanded reproduction must be taken into consideration.

It directly affects the production process. Every year more than $60 \%$ of Lukoil personnel attend advanced training programs. A system of distance learning (over 250 courses), involving 54 organizations of Lukoil Group, has been created. It also includes recreation processes (maintenance of health resorts, arrangement of treatment or recreation for employees, etc.).

It is necessary to build an efficient system of retaining qualified staff, which can be achieved on the basis of an effective social policy encouraging long-term interactions [5]. Thus, Lukoil regularly monitors management approaches to motivation; about $95 \%$ of the average number of employees form the funded part of labor pensions in the Non-State Pension Fund LUKOIL-Garant .

Since 2014 the company has implemented a special assessment of working conditions in accordance with federal laws (Labor Code of the Russian Federation) aimed at differentiation policy of compensation for heavy work and work in harmful or hazardous working conditions (in the form of a reduced working week, additional paid holiday, increased salary etc.), depending on the degree of harm caused.

\section{Social organizations.}

The interaction of the company with public organizations testifies the expansion of spheres of its influence and enhances its significant image not only in the economic activities.

The level of non-governmental organizations can range from regional to supranational with different models of interactions.

Corporate operations of PJSC Lukoil include [1]:
- regional level - organization of social and cultural events, sport competitions etc.

- national level - participating in business associations including the Russian Union of Industrialists and Entrepreneurs; support of the Russian Geographical Society (agreement on cooperation in the development of research and popularization of science, etc.);

- supranational level - cooperation with international organizations. The company has joined the project Green Office of the Russian branch of Greenpeace, taking voluntary commitments to improve office ecology.

- PJSC Lukoil is the only Russian company cooperating with the International Labour Organization (partnership regarding youth employment, personnel exchange and organization of teaching process).

In addition a significant group of entities associated with the company's activities - distributors, intermediaries, R\&D companies, consumers, etc. - must be mentioned in the context of a company interaction system [6,7]

The company can change the content of economic interactions showing increased demands in particular programs implementing [8,9]. For example, since 2010 Lukoil has been delegating (on a competitive basis) a part of petrol stations to the experienced dealers knowing the region. Dealers are rewarded for selling fuel, the company covers costs for banking services adapting to changes in the the economic environment.

Lukoil has left behind the requirements of technical regulations and its own plans regarding the terms of production launch of motor fuels of Euro 5 standard.

In addition, competitive advantages of the company influence the business of its partners. Thus, LLC LukoilAero cooperates with aircrafts in over 30 destinations in Russia and abroad, aiming to meet the airlines' need in high quality fuel, because it can affect the safety of air travel [1].

\section{CONCLUSION}

Thus, a variety of economic interactions and determines various ways of their establishment and management.The transformation of parameters can be initiated by any economic entity. However, the degree of adaptation to the changes to a certain extent depends on the kind of changes and the empowerment of the initiator. An effective interaction system, ensuring the ongoing development of the society includes:

- general milestones of the entities (or effective motivation tools);

- coordination / harmonization of the institutional activities of the interacting entities;

- involvement of a wide range of entities interested in the process of amendment

The government authorities, public and media of four 
federal districts (including representatives of the Federation Council, State Duma, the Russian Ministry of Natural Resources, Ministry of Energy of Russia, Federal Service for Supervision of Natural Resource Usage, Greenpeace-Russia, the United Nations Development Program in Russia, company Bureau VERITAS Certification, enterprises of fuel and energy sector, consulting and environmental organizations) attended the roundtable discussion of modernization program of Lukoil production that took place in Moscow in the Russian Geographical Society.

- Creation of communication system with the entities (public polling, counseling offices, etc.).

- beneficial effect on the economic system in general (The contest of social and cultural projects organized by PJSC Lukoil is acknowledge the prize winner of the first National program Best Russian Social Projects in the category Socially Oriented Competitions. The program is supported by the Ministry of Labour and Social Development of the Russian Federation, the Ministry of Natural Resources and Environment of the Russian Federation, the Agency of Strategic Initiatives, World Wildlife Fund (WWF), the Forest Stewardship Council (FSC) and other public institutions.)

- going beyond the economic activities (PJSC Lukoil participated in the organization of exhibitions in the State Tretyakov Gallery, the Russian Museum etc.)

\section{REFERENCES}

[1] Sustainability Report of PJSC Lukoil, Martch 12, 2016 URL:http://www.lukoil.ru/materials/doc/social/2013/Book_SO_rus_s.pd $\mathrm{f}$

[2] E. G. Matugina, N.A. Yarushkina Investments in the development of the territory as a tool of establishment of a socially responsible company image (on the example of oil and gas industry) // Ekonomika i predprinimatelstvo (Economics and Entrepreneurship), 2016, vol. 1, pp. $1098-1102$.

[3] A. Vazim, V Romanyuk, K Ahmadeev and I Matveenko "Associated petroleum gas utilization in Tomsk Oblast: energy efficiency and tax advantages," IOP Conference Series: Earth and Environmental Science, 2015, vol. 27, 5 p., http://dx.doi.org/10.1088/1755-1315/27/1/012078

[4] Yu. S. Makasheva, N. P. Makasheva, V. V. Remnyakov, B. S. Burykhin and I.V. Shenderova. "Petroleum staff reluctance and adjustment to innovative changes" IOP Conference Series: Earth and Environmental Science, 2015, vol. 27, 5 p.

[5] E. G. Matugina, O. V. Pogharnitskaya, K .O. Petrova and A. B. Strelnikova "Intensive use of energy resources regarding sustainable cities ", IOP Conference Series: Earth and Environmental Science, 2015, vol. $27,4 \mathrm{p}$.

[6] R. S. Groot, M. A. Wilson, R. Boumans, "A typology for the classification, description and valuation of ecosystem functions, goods and services", Ecological Economics 41, 2002, pp. 393-408.

[7] De Montis, A., Caschili, S., Mulas, M., Modica, G., Ganciu, A., Bardi, A., Ledda, A., Dessena, L., Laudari, L. and Fichera, CR. "Urban-rural ecological networks for landscape planning”. Land Use Policy, 50, 2016, pp. 312-327.

[8] Millennium Ecosystem Assessment, Ecosystems \& human well-being: synthesis report, Island Press, 2005.

[9] M. Tsibulnikova, I. Sharf, "Valuing Ecosystem Services in Wildlife Management ". Proceedings of the 26th International Business Information Management Association Conference, Madrid, Spain, November 11-12, 2015, pp. 1054-1059. 